TRANSLATORIUM

Nikołaj Łosski

\title{
IDEAŁ CHRZEŚCIJAŃSKI A KULTURA TECHNICZNA
}

\author{
Z języka rosyjskiego przełożyt i przypisami opatrzyt \\ Jarosław Młynarczyk
}

\section{OD TLUMACZA}

Podstawą przekładu jest: Николай Лосский (Nikołaj Łosski), ТЕХНИЧЕСКАЯ КУЛЬТУРА И ХРИСТІАНСКІЙ ИДЕАЛЬ (Techniczeskaja kultura i christianskij ideał), zamieszczonego w czasopiśmie „ПУТЬ. ОРГАНЬ РУССКОЙ РЕЛИГІОЗНОЙ МЫСЛИ” (Put. Organ Russkoj Religioznoj Mysli), red. Н. А. Бердяев, No. 9, Paris 1928, s. 3-13.

Jarosław Mtynarczyk

(Biatystok) 


\section{Nikołaj Losski}

\section{Ideał chrześcijański a kultura techniczna}

W głębiach mateczników Rosji nierzadko zaobserwować można jak włościanin, na widok pędzącego pociągu, auta lub samolotu, kreśli znak krzyża i mamrocze „Zgiń,

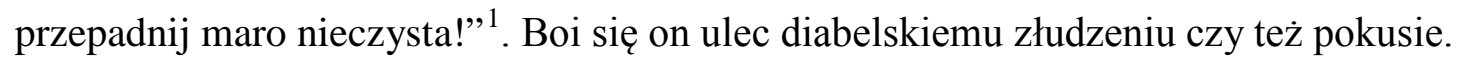

Tego przesądnego strachu nie odczuwa wykształcony wyznawca prawosławia, jednak również i on, jeśli tylko jest przesiąknięty do głębi swej duszy prawosławiem, uważa za zło i diabelskie kuszenie nadmierne zainteresowanie kulturą świecką, w szczególny sposób kulturą techniczną.

Oświecony Europejczyk postrzega takie poglądy jako przejaw zacofania przyjmujących je ludzi oraz „reakcyjny” charakter prawosławnej i w ogóle kościelnej religijności. Jednakże dobrze znanym faktem jest wielka powierzchowność osiemnastowiecznego „oświecenia”. Toteż niczym zaskakującym zdaje się być podejrzenie zaprzątające nasz umysł, a mianowicie to, czy aby „oświecenie” XX wieku nie jest równie powierzchowne. Zobaczmy zatem czy prostoduszny prawosławny nie posiada głębokich, poprawnie ujętych, chociaż zarazem niezidentyfikowanych dotychczas, przyczyn nieufności odnoszącej się do kultury technicznej.

$\mathrm{Na}$ czym koncentrują się myśli prawdziwego chrześcijanina, co jest ostatecznym kresem jego nadziei? Oczywiście jedność z Bogiem i wszystkimi Jego stworzeniami oraz wznoszenie Królestwa Bożego na fundamencie miłości, gdzie Bóg jest „wszystkim dla wszystkich” ${ }^{2}$. W Królestwie tym mnóstwo żywych istot tworzy „Jedno Ciało i Jeden Duch ${ }^{3 ”}$. W Królestwie tym nie ulega zatraceniu indywidualność duszy ludzkiej, nie gaśnie w nim osobowość. Chrześcijanin oczekuje zmartwychwstania w ciele, stąd też ma nadzieję na zachowanie indywidualnego duchowo-cielesnego istnienia. Tym niemniej przyznaje, że wiele duchowych i cielesnych indywidualności tworzy „Jedno Ciało i Jeden Duch” w Królestwie Bożym. Jak możliwa jest taka jedność? Otóż możliwa jest ona jedynie w przypadku, kiedy to mnóstwo osobowości ogarniętych jest tak doskonałą miłością do siebie nawzajem i Boga, że żyją zupełnie jak Jeden Duch, a zatem: 1) myśl każdego jest bezzwłocznie ${ }^{4}$ wiadomą

\footnotetext{
${ }^{1}$ W oryginale: „“Съ нами крестная сила»!”.

21 Kor $15,28$.

${ }^{3}$ Ef 4, 4.

${ }^{4}$ Wszelkie wyróżnienie $w$ tekście pochodzi od autora.
} 
wszystkim; 2) pragnienie każdego jest bezzwłocznie podchwytywane i wspólnotowo, przez wszystkich, zaspakajane. Tak całkowita jedność wielu osób jest ich konkretna wspótistotnością ${ }^{5}$ : we wszystkich stworzeniach tego królestwa, w tysiącach indywidualnych odkryć, urzeczywistnia się Jeden Duch - Chrystus; każde indywidualne ciało jest narządem Jednego Ciała Chrystusa ${ }^{6}$, duchowego, przemienionego, w którym nie ma oddalenia, które nie pozostaje nieprzystępne, ale w którym w sposób doskonały urzeczywistnione jest wzajemne przenikanie się ciał. Takie nieskończenie złożone, jednakowoż całościowe królestwo życia zapewnia każdemu swemu członkowi, pozostającemu jednak indywiduum, nieskończoną pełnię istnienia i równie nieskończoną siłę twórczości, ponieważ nie istnieje tu wymienność, lecz przeciwnie, istnieje idealna synergia sił.

Czyż w kierunku osiągnięcia tego ideału zmierza współczesna kultura techniczna? Czyż pokonuje ona oddalenie stworzeń w czasie i przestrzeni? $\mathrm{Na}$ to pytanie wielu, bez zastanowienia, udziela odpowiedzi: „Tak, oczywiście. Szybkie pociągi, samochody czy samoloty niesłychanie zmniejszyły dystans między różnymi punktami na Ziemi. Powierzchnia jej zmniejszyła się w jakimś stopniu, jakby kilka dziesiątków razy, bynajmniej nie utraciwszy swojego bogactwa i różnorodności. Za sprawą telegrafu, telefonu i radia to zjednoczenie zostało osiągnięte $\mathrm{w}$ jeszcze większym stopniu. Papież mógłby sprawić, aby jego homilię, nieomal w momencie jej głoszenia, słyszano we wszystkich kościołach katolickich na całej Ziemi. Bliski jest czas, w którym to urządzenia radiowe pozwalać będą nie tylko na odbiór fonii, lecz i widzenie przedmiotów na odległość: wówczas to odbywający się w Londynie wiec polityczny czy pogrzeb wielkiego człowieka w Paryżu będzie widoczny we wszystkich zakątkach świata. Osiągnięta wówczas będzie multipraesentia ${ }^{7}$ rzeczywistości, jakoby urzeczywistnienie przedmiotu natychmiast w wielu miejscach. Czyż nie jest to zwycięstwo nad czasem i przestrzenią, nad oddaleniem dzielącym stworzenia w nich będące a osiągniętą naturalnymi środkami, bez Boga i Jego Królestwa...?”.

Istnieje jednak jeszcze jedna cecha chrześcijańskiego ideału Królestwa Bożego, tj. nadzieja na osiągnięcie pełni istnienia oraz aktywności twórczej. Obrońca współczesnej kultury i tu odpowie nam, jednak być może nieco się przedtem zawaha: „Nie ulega wątpliwości, że współczesnej kulturze towarzyszy wzrost złożoności i zmyślności, a zatem

\footnotetext{
${ }^{5}$ Aby zauważyć różnicę między konkretnq a abstrakcyjnq współistotnościq zob. mojq ksiqż̇ę „Świat jako organiczna całość” («Міръ какъ органическое цьлое»), a także ksiqż̇ę „Wolność woli” (“Свобода воли»).

Obie książki nie doczekały się jeszcze przekładu na język polski. Przypisy od autora będę oznaczał czcionką pogrubioną i kursywą.

${ }^{6} 1$ Kor $12,12.14$.

${ }^{7}$ Z łac. „Wszechobecność”. Jeden z przymiotów przypisywanych Bogu.
} 
i pełni życia. W naszych czasach ważna osoba publiczna może w ciągu jednego dnia wykonać ogromną ilość prac, nawiązać stosunki z mnóstwem ludzi, doświadczyć ogromu wrażeń, po czym, na koniec, doznać szeregu przyjemności: negocjacji politycznych, spekulacji giełdowych, wymiany ogromnej ilości korespondencji, wizyty w różnych częściach miasta, przejażdżki samochodem po podmiejskiego parku, a wieczorem udać się na spektakl. Wszystko to może być zawarte w planie jednego dnia i to w takiej ilości, że potrzeba by całego miesiąca życia w XVIII wieku, aby zrealizować każdą z tych aktywności. Lecz nie tylko znakomite osobistości, ale i najskromniejsi robotnicy doświadczają w tej samej proporcji złożoności życia: porównajcież czynności konduktora dyliżansu jeżdżącego między dwoma angielskimi miastami na początku XIX wieku i te konduktora dzisiejszego londyńskiego tramwaju. Jak wielką jest różnica w liczbie czynności służbowych, w ilości spotkań z ludźmi i stosunkowo trudnych kombinacji ${ }^{8}$, wymagających natychmiastowej reakcji i działania!”.

Jednakże, jeśli od ilościowych komplikacji życia zwrócimy się do pytania o podniesienie jego poziomu jakościowego, zwłaszcza w pytaniu o to, czy istnieje we współczesnej kulturze wzrost jakości twórczości, wszyscy stwierdzą, iż niemal na pewno nie zrealizowane zostało takie udoskonalenie życia; niemal na pewno jakość nie nadąża za ilością. Wówczas w naszej duszy rodzi się wątpliwość; przed nami pojawia się budzące trwogę pytanie o to, czy na drodze, którą zmierzamy wszystko jest właściwym. Ażeby odpowiedzieć na to pytanie, poddamy analizie sposoby, jakimi współczesna kultura osiąga złożoność życia, będąc w świadomości sił jakie wykorzystuje ona doskonaląc technikę.

W tym celu rozważmy, po pierwsze, środki transportu w przestrzeni: parowozy, parostatki, samochody, samoloty itp.. Wszystkie te maszyny oparte są o użycie siły odrzutu, tj. dokładnie technicznej siły, która już w swej nazwie wskazuje na odłaczenie. Jeżeli więc mogą one doprowadzić do zjednoczenia, to jedynie zewnętrznego, ograniczając się tym samym do przestrzennej jedynie bliskości. Jeśliby rzeczywiście wspominano mi o tramwaju i innych sposobach wykorzystania elektrycznej siły przyciągania ${ }^{9}$, nie wpłynęłoby to w jakikolwiek sposób na moją tezę. Nie tylko tramwaj, lecz i każda inna maszyna zakłada użycie siły przyciągania. Ot, na przykład, wymagają jej użycia wszystkie części stałe

\footnotetext{
${ }^{8}$ Trudno ocenić, czy chodzi tu o trudność kombinacji działań wiązanych z prowadzeniem pojazdu szynowego, czy o kombinacyjne obchodzenie się z pasażerami, np. dostosowywanie swego sposobu wysławiania się do sposobu, w jaki mówi pasażer.

${ }^{9}$ W oryginale: „электрической силы притяженія”. Chodzi tu o nazwane Prawem Coulomba (1785 r.) prawo fizyki, opisujące siłę oddziaływania elektrostatycznego ładunków elektrycznych, a konkretnie o fakt, iż ładunki różnoimienne przyciągają się.
} 
maszyny, dlatego że ma miejsce sprzężenie jej cząsteczek. Jednakże we wszystkich tych przypadkach cel techniczny jest osiągany jedynie w takim stopniu, w jakim siła przyciągania jest, w sposób niezbędny, połączona z siłą odrzutu. Użycie tych sił prowadzi do zbliżenia z każdym dowolnym punktem A, nie inaczej niż drogą oddalenia od każdego dowolnego punktu B: przybliżając się do Paryża tracę Moskwę lub Sankt Petersburg. Jak powiedziałem, to jednak nie wystarczy a moje najbliższe nawet zbliżenie ma jedynie odniesienie zewnętrzne. Jest to przylgnięcie czasoprzestrzenne, przy którym może pozostać lub nawet wzrosnąć wewnętrzna obcość, nieobecność wzajemnego przenikania się między tym, co stało się zewnętrzne bliskie lub nawet przylegające.

Prawie wszystkie dziedziny naszej kultury technicznej mają na celu stworzenie zewnętrznego zbliżenia albo rozdzielenia. Miejsca zamieszkania i odzież chroni się przed bezpośrednim oddziaływaniem sił natury. Pozyskiwanie, przechowywanie i przetwarzanie substancji odżywczych itp. - wszystko to jest działaniem mechanizmu służącemu zewnętrznemu jednoczeniu i połączeniu. W wyższych nawet obszarach, stojących u granic szczytu kultury technicznej, np. medycynie, w znacznej mierze dzieje się to samo. Najbardziej rozwinięte, dokładne i udoskonalone sposoby leczenia prezentować ma chirurgia, lecz nawet leki medycyny współczesnej, w większości przypadków, mają charakter trucizny, a ich działanie na organizm ma charakter przemocy.

Zdając sobie sprawę z opisanych cech naszej kultury technicznej, przestaniemy być nadmiernie dumni z poszerzenia świata życia osiągniętego w XX wieku. Osiągane przez nas zjednoczenie świata i nasza jedność ze światem okazują się być nieprawdziwymi. Jest to połączenie, które związane jest z rozdzieleniem; kumulacja wewnętrznie oddzielonych agregatów $w^{10}$ - słowem, jest to przeogromne fałszerstwo, imitacja jedności.

Nie dziwi więc, że poszerzenie naszej świadomości, uzyskane na skutek udoskonalania środków zewnętrznego kontaktu ze światem, okazuje się być nieorganiczne. Mnóstwo wrażeń i działań, mających za swą podstawę zewnętrzne relacje ze światem, nie wykształca w naszej duszy harmonijnej jedności, całości, w której to elementy potrzebują i wzmacniają siebie wzajemnie a w związku z tym: im jest ich więcej, tym system jest trwalszy. Przeciwnie, nagromadzone w formie chaotycznej grupy, w której wiele elementów

\footnotetext{
${ }^{10}$ W oryginale również pada to słowo („azгрегamoвъ”). Łosski w ten sposób zwraca naszą uwagę na fakt, że kultura techniczna postrzega wnętrze człowieka jedynie jako zespół narządów, które jak połączone maszyny wykonują określoną pracę. Podobnie sprawa ma się w ujęciu społecznym. Każdy agregat działa samodzielnie, mimo iż znajduje się blisko innego agregata - nie jest od niego zależny. Chociaż ich praca w tym samym czasie w efekcie przynosi kulminację mocy, np. w przypadku agregatów prądotwórczych, nie jest to ich wspólne, oparte o relację działanie.
} 
pozostaje ze sobą w sprzeczności,osłabiają się nawzajem i prowadzą do osłabienia całego ustroju duszy. Stąd rozprzestrzenianie się chorób psychicznych ${ }^{11}$ we współczesnym społeczeństwie: nerwowość, histeria, psychastenia, niezadowolenie z życia, samobójstwo rozprzestrzeniają się w groźnych rozmiarach.

„Czegóż ty pragniesz? - zadadzą mi pytanie - Aby usunąć czasowe i przestrzenne rozdzielenie, aby je przezwyciężyć, nie istnieje w ogóle inna droga niż ta, którą podąża ludzka kultura.” Nie, jest inna droga, odpowiem. Ostateczny cel tej prawdziwej drogi zawiera się w chrześcijańskim ideale „Jedno Ciało i Jeden Duch”. Sednem tej drogi jest osiągnięcie pełnej, konkretnej współistotności w oparciu o doskonałą miłość. Jednakże, co stwierdzam z żalem, jesteśmy tak daleko od urzeczywistnienia tego ideału, że istnieje ryzyko, iż odnoszenie się do niego stanie się pustosłowiem. Ażeby w pełni zrozumieć drogę wiodącą do ideału i opisać różne jego strony za pomocą pojęć abstrakcyjnych, zadajemy sobie pytanie $\mathrm{o}$ to, czy w życiu codziennym istnieją chociaż wczesne znamiona ruchu w kierunku doskonałej jedności. Czyż nie ma przykładów konkretnej współistotności, choćby ograniczonej, dającej nie kosmiczną całość, ale całość przynajmniej kilku prowadzących działania indywiduów ${ }^{12}$, zjednoczonych $\mathrm{w}$ formie częściowego wzajemnego przenikania się...? Przykład ten znajdziemy w jedności naszego własnego organizmu. Ciało nasze zawiera W sobie mnóstwo komórek, a każda z nich jest stosunkowo samodzielnym organizmem, istotą żywą. Mało tego, każdy atom, a nawet elektron jest samodzielną jednostką, będącą niezależnym centrum działania. Niemniej, to mnóstwo prowadzących działania indywiduów tworzy stosunkowo spójną jedność, dokonując skoordynowanych działań pod kierunkiem lidera $^{13}$, jakim jest moje 'ja'. Pomimo złożoności przestrzennej mojego ciała, jestem obecny we wszystkich jego częściach swoją świadomością, odczuciami i wolą. W rzeczywistości, mając na uwadze takie fakty, jak świadomość bólu spowodowanego skaleczeniem palca, głodu, pragnienia, pełnej wigoru aktywności fizycznej, itp. można mówić o moim ‘ja' jako obecnym w sposób pełny (omnipraesentia) w ciele za sprawą świadomości i wiedzy. Obserwując takie fakty, jak dowolne skurcze mięśni, wpływ moich emocji na wszystkie odruchy $^{14}$ ciała, możemy mówić także o pełnej obecności mojego 'ja' w ciele poprzez wolę i uczucie.

\footnotetext{
${ }^{11}$ W oryginale: „душевныхъ бользней”. W języku rosyjskim zachował się zupełnie źródłowy przekład słów „psychiczny”, „psychiczna” wywodzących się przecież od greckiego 廿uxń , tj. „dusza” właśnie.

${ }^{12}$ W oryginale: „дьятелей".

${ }^{13}$ W oryginale: „высшаго дьятеля".

${ }^{14}$ W oryginale: „отправленія”.
} 
Ta pełna obecność ‘ja' w ciele nie jest szybkim ruchem 'ja' od jednej do drugiej komórki wewnątrz ciała, jak również nie jest ruchem komórek ku 'ja'. Prawdą jest, że do połączenia 'ja' z komórkami niezbędna jest jedność i całość układu nerwowego, tj. coś przypominającego sieć telegraficzną, jednakże prądy przepływające przez nerwy czuciowe w tym układzie wyraźnie są jedynie motywami, zaledwie bodźcami, zachęcającymi moje 'ja' do tego, ażeby skoncentrowało bezzwłocznie swoją uwagę na procesach życiowych tego czy owego rejonu swojego ciała. W rzeczywistości ból spowodowany skaleczeniem palca jest odczuwalny jako bardzo bolesny stan komórek palca, nie jest on natomiast symbolem, który nie oddaje bólu, a jedynie reprezentuje go w moim umyśle. Źródłem mojej wiedzy o tym bólu jest bezpośrednia intuicja i bezzwłoczne współuczestnictwo mojego ‘ja’ w katastrofalnym stanie członka mego ciała.

$\mathrm{Z}$ racji tego, iż cały świat został zbudowany wedle tych samych pryncypiów, wiadomości telegraficzne donoszą, np., że „Zachorował cesarz japoński.”15. Jest to nic innego, jak motyw ku temu, aby moje 'ja' dokonało aktu intuicji, ukierunkowanego na zdarzenie „zachorował cesarz”, wydarzające się w położonej daleko ode mnie Japonii. Jednakże jak wielką jest różnica między intuicją, ukierunkowaną na bolesny stan mojego palca i intuicją, przywodzącą na myśl obcego mi cesarza! W pierwszym przypadku W świadomości istnieje skonkretyzowana pełnia zdarzenia i doświadczenie intymnej bliskości, natomiast w drugim - chłodne przywołanie na myśl. Takąż samą różnicę odnajdziemy również i w sferze wolitywnej, np. między dowolnym skurczem mięśnia mojej ręki i wykonaniem przez rządcę ${ }^{16}$ mojego, zleconego poprzez telegraf, polecenia „Przyślij pieniądze.”. Moja intymna bliskość z organami ciała tak jest wielką, iż można rzec: „Działam w swoich mięśniach.”, lecz nie można rzec: „Działam w rządcy.”. Aktywne elementy organizmu w ich wzajemnym stosunku do siebie nie są obcymi: konfrontacja co najmniej częściowo jest zażegnana, obcy stał się swoim; kocham swoje ciało i ciało moje mnie kocha. Za przykład posłużyć może pełna poświęcenia walka fagocytów toczona przeciw patogenom, od początku mająca charakter służby całości, a nie troski o siebie. W ten sposób w organizmie dokonuje się konkretna współistotność w oparciu o miłość; $\sigma v \mu \pi \alpha \theta \varepsilon ı \alpha$ stoików jest rozwinięta w większym stopniu ${ }^{17}$. Objawia się to, po pierwsze - w całościowym charakterze intuicji,

\footnotetext{
${ }^{15}$ W oryginale: „забольлъ японскій микадо”. „Mikado” (dosł. z jap. „Wysoka brama”) to przestarzały tytuł odnoszący się do cesarza Japonii, który jest obecnie często nazywany „Tenno” („Syn Niebios”). Termin „Mikado" początkowo oznaczał nie tylko samego monarchę, ale także jego dom, posiadłość, a nawet państwo.

${ }^{16}$ W oryginale: „управляющему”.

${ }^{17}$ Wedle nauki stoików wszystkie elementy świata znajdujq się we wzajemnym ścisłym oddziaływaniu, tak iż

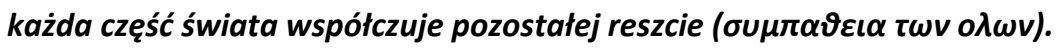


a po drugie - w pogodzeniu między sobą dążeń rozlicznych części zdrowego organizmu, a zwłaszcza z dążeniami tego 'ja', które stoi na czele organizmu. W każdej minucie życia mojego organizmu dokonuje się najbardziej intymne zjednoczenie następującego rodzaju, dotyczące dwóch lub większej ilości prowadzących działania indywiduów: moja wola jakoby bezzwłoczne oddziałuje w innej istocie, mianowicie w dowolnym organie mojego ciała, np. w mięśniach, przy czym siła przynależy tej drugiej istocie, lecz motywy tej siły, to znaczy jej kierunek, wskazanie jej celów, pochodzi z mojego ‘ja'. Taki wpływ mojego 'ja' na organy mego ciała podobny jest temu, co można byłoby nazwać magią, magicznym oddziaływaniem. Należy jednak natychmiast dokonać pewnego zastrzeżenia: tak ścisłe połączenie prowadzących działania indywiduów, w którym jedno $\mathrm{z}$ nich porzuca jakiekolwiek odniesienie do swojej niezależności i przeobraża się w narzędzie podległe drugiemu, osiąga się dwoma, głęboko się od siebie różniącymi, sposobami - na drodze przemocy, tj. wskutek strachu lub zwiedzenia oraz na drodze współczującej sympatii, zgody opartej o miłość ${ }^{18}$. Tylko pierwszy przypadek wpływu jednej woli na drugą ${ }^{19}$ powinien być nazwany słowem magia, natomiast drugi będziemy nazywać słowem - jednomyślnośćc ${ }^{20}$ lub konkretna współistotność. Najwyższy stopień tej jednomyślności osiągany jest w organizmie, między tymi jego częściami, które do połączenia swoich działań nie potrzebują nawet neuroprzekaźników ${ }^{21}$.

A zatem, w organizmie w ogromnej mierze realizuje się autentyczna wewnętrzna jedność, a technika stwarza jedynie iluzoryczną - zewnętrzne zbliżenie, nieorganiczną bliskość w czasie i przestrzeni. Bergson dla ukazania tej różnicy używa terminów organizacja i fabrykacja ${ }^{22 .}$ Technika i jej procesy fabrykacji stwarzają kontakt ze światem i oddziaływanie na świat zewnętrzny za pomocą narzędzi. Organizacja natomiast stwarza kontakt wewnętrzny za pośrednictwem organów ontologicznie przeobrażając środowisko, asymilując je, przekształcając je $\mathrm{z}$ obcych mi form bycia $\mathrm{w}$ organ mojego ciała albo przekształcając mnie w organ istoty wyższej niż człowiek. Otóż taka jest odpowiedź na

\footnotetext{
${ }^{18}$ W oryginale: „любовнаго согласія”.

${ }^{19}$ W oryginale: „одной воли въ сферу другой”.

${ }^{20} \mathrm{~W}$ oryginale pada tu słowo: „eдuнодyuie”, które po raz kolejny wskazuje na „osoby obdarzone wspólnym 21 duchem". Niestety w języku polskim nie istnieje odpowiedni wyraz, który mógłby oddać ten niuans.

Metalnikow.

Chodzi zapewne o wskazanie prac Siergieja Iwanowicza Metalnikowa (1870-1946), uczonego, profesora uniwersytetu w St. Petersburgu, od 1918 roku związanego z Instytutem Pasteura w Paryżu. Jego badania uchodziły za innowacyjne, a dotyczyły interakcji neuroimmunologicznych. Dowiódł on bliskiej interakcji między układem odpornościowym i nerwowym.

${ }^{22}$ W celu zgłębienia tej różnicy, zob. Dawid Wł. J., O Filozofji Bergsona, „Nowe Twory”, Warszawa 1914.
} 
pytanie, dotyczące tego, jaką inną drogę, prócz techniki, można obrać w celu właściwego udoskonalenia życia - ta droga to rozwój organizacji.

Wcześniej niż opowiem o tym jak można wyobrażać sobie rozwój naszego organizmu, powiem kilka słów o już osiągniętym utrwaleniu i udoskonaleniu. Nasz własny organizm nie jest projektem w pełni zamkniętym: ideał jednomyślności i harmonijnej współpracy nie został zrealizowany nawet i w granicach naszego ciała. Ten fakt w szczególności uobecnia się w przypadku choroby. Wówczas uciekamy się do zażywania środków odurzających, do bromu, opium itp. leków, gdy tymczasem w pierwszej kolejności, myśląc rozumnie, należałoby próbować wzbudzić siły harmonizujące samego organizmu. Ku temu celowi mogłyby prowadzić różne rodzaje psychoterapii. Przede wszystkim wskazałbym na ten rodzaj psychoterapii, który może być ugruntowany ${ }^{23}$ na nauce o organizmie, jak to jest w przypadku wspólnoty żywych prowadzących działania indywiduów, między którymi panuje zwykle dobre zrozumienie. Taką naukę można by oprzeć na metodzie autosugestii zaproponowanej przez Coue ${ }^{24}$. Istota tej metody przedstawia się następująco: chory, który np. ma tiki nerwowe, stara się osiągnąć stan autosugestii i pokonać bezsensowne skurcze mięśni uciekając się nie do woli, lecz do wyobrażenia. Nie wydaje on rozkazów organom swojego ciała, nie stara się podporządkować ich sobie drogą wolitywnej przemocy, a jedynie w swoim umyśle za pomocą wyobrażenia tworzy on żywe przedstawienie siebie, jako człowieka żyjącego normalnym, harmonijnym, dającym pełne zadowolenie życiem. Taka autosugestia jest jakoby próbą wywołania dobrowolnego zainteresowania niższych ośrodków organizmu ideałem normalnego, zdrowego życia. Taki koncept podobny jest działaniu dowódcy, który nie rozkazuje, nie grozi, lecz porywa pułki za sobą tym, że chwytając sztandar sam pędzi naprzód.

Innym rodzajem psychoterapii harmonizującej duszę i ciało jest psychoanaliza Freuda, stosowana $\mathrm{w}$ leczeniu nerwic ${ }^{25}$. Zadaniem psychoanalizy jest odnalezienie traumy, która doprowadziła do choroby psychicznej (urazu psychicznego, który nie zawsze sprowadza się do niezaspokojonych potrzeb seksualnych, jak sądzą niektórzy skrajni freudyści). Ona to, będąc odsuniętą $\mathrm{w}$ podświadome podwaliny duszy, pełni rolę jakby drzazgi, jakby ciała obcego, wyzwalającego szereg zjawisk, naruszających całość i harmonię życia duchowego i cielesnego. Zdając sobie sprawę z elementu naruszającego całość życia duchowego psychoterapeuta eliminuje jego szkodliwe oddziaływanie, np. drogą harmonizującej

\footnotetext{
${ }^{23}$ W oryginale: „построенъ”.

${ }^{24}$ Emile Coué (1857-1926), francuski psycholog i farmaceuta. Wprowadził metodę psychoterapii, kojenia i samodoskonalenia, opartą na autosugestii lub samo-hipnozie.

${ }^{25}$ W oryginale: „для изльченія психо-неврозовъ”.
} 
sublimacji (przesuwając niezaspokojoną namiętność ku wzniosłej postaci). Zatem męki niezaspokojonej miłości w życiu małżeńskim, prowadzące do ciężkiej nerwicy, mogą być uleczone harmonijnym skupieniem wszystkich sił na matczynej miłości realizującej się w wychowaniu dziecka.

Organiczne metody leczenia duszy i ciała, do których medycyna zaczyna z wolna docierać, od dawna znajdowały się w religii chrześcijańskiej. Wśród prawosławnych i katolików sakrament pokuty, związany ze spowiedzią, jest potężnym środkiem gojenia duchowych ran oraz odbudowy całości duszy. Zawiść, niespełnione ambicje, nienawiść uświadamia sobie penitent ${ }^{26}$ na spowiedzi; źródła tych naruszeń harmonii zostają wyjaśnione poprzez naprowadzające spostrzeżenia przenikliwej i współczującej ludzkiej duszy kapłana. Wszystko to zachodzi w atmosferze pobudzenia wyższej siły - ducha, poszukującego pojednania i wzniosłego duchowego pokoju w warunkach sprzyjających sublimacji. Siła wierzącego jest połączona z miłosierną mocą Kościoła i jego Głowy - Chrystusa i w jego duszy zachodzą głębokie zmiany, dzięki którym odnowiona zostaje harmonijna relacja ze światem zewnętrznym a wraz $z$ nią $i$ wewnętrzna harmonia duszy. Wraz z tym uzdrowieniem ducha dochodzi zwykle do harmonizacji życia cielesnego. Ten uzdrawiający wpływ religii jest faktem potwierdzonym badaniami naukowymi. Prof. Masaryk w swojej książce „Samobójstwo jako masowe zjawisko społeczne”27 - na podstawie analizy mnóstwa danych statystycznych - dochodzi do wniosku, że liczba psychoz i samobójstw wzrasta równolegle z utratą religii i równolegle ze zmniejszeniem głębi uczuć religijnych.

Dotychczas mówiłem o udoskonalaniu życia metodami organizacji, a nie techniki, poprzez zastosowanie ich do naszego ludzkiego organizmu. Przejdźmy zatem dalej. Porównując organizm jednokomórkowy z naszym, znacznie bardziej złożonym organizmem wielokomórkowym, dowiemy się, że ewolucja ma tutaj charakter rozszerzania sfery organicznej jedności, włączając coraz więcej i więcej nowych istot (komórek) w przyjazne stowarzyszenie prowadzących działania indywiduów. W znacznej mierze zaprzestały one wzajemnej ze sobą walki, przeżywając - mniej lub bardziej - wspólne życie. Skoro ten stan został osiągnięty na drodze rozwoju od organizmów niższych aż do człowieka, dlaczegóż by

\footnotetext{
${ }^{26}$ W oryginale: „кающимся”.

${ }^{27}$ W oryginale: „"Der Selbstmort als soziale Massenercheinung»”. Książka Tomasa G. Masaryka (1850-1937) wyd. po raz pierwszy w Wiedniu w roku 1881. Dotychczas nie doczekała się przekładu na język polski.

Sam Masaryk, uczony, filozof i pierwszy prezydent Czechosłowacji był przyjacielem Łosskiego. Po wydaleniu ze Związku Radzieckiego, Masaryk zaprosił go do swojego kraju, gdzie Rosjanin rozpoczął wykłady na uniwersytetach w Pradze, Brnie i Bratysławie.
} 
nie można było osiągnąć i więcej w formie stworzenia organicznych jedności wyższych niż ludzkie ciało, w postaci takich organizmów, w które człowiek byłby włączony jako element, podobnie temu, jak to jest z komórką - np. kulista czerwona krwinka jest elementem ludzkiego ciała. Warto zadać o to pytanie, na które narzuca się i odpowiedź: takie stopnie $\dot{z ̇ y c i a}^{28}$, takie nad-biologiczne ${ }^{29}$ organizmy istnieją. W rzeczy samej, rodzina ${ }^{30}$ pszczół w każdym ulu, społeczność mrówek w mrowisku tworzy jedną całość, w której każda pszczoła i mrówka z osobna służy całości tak, jak komórka w naszym organizmie. Całość natomiast ula albo mrowiska jest istotą wyższego rzędu niż pojedyncza czoła lub mrówka. Całość ta realizuje całościowe działania celowe, które są niedostępne oddzielnym osobom, wchodzącym w jej skład. Dokładnie w ten sam sposób państwo, naród i ludzie są żywą istotą wyższego rzędu niż poszczególne osoby wchodzące w jego skład ${ }^{31}$.

Jak bardzo rozmaite są te jednostki życia wyższego rzędu, wnosić można i z tego, że las, torfowisko, jezioro itp. mogą być uznawane za całościowe istoty żywe. Współczesne przyrodoznawstwo jest coraz bardziej zainteresowane takimi jednościami i odkrywa w nich procesy wskazujące na organiczną koordynację ich elementów między sobą. Dają one prawo do uznania tych jedności za organizmy wyższego rzędu. Filozofia od dawna rozwija taki sposób badania struktury świata, zgodnie z którym każdy odrębny organizm jest elementem jakiejś bardziej złożonej organicznej całości, a ten z kolei wchodzi w skład jeszcze wyższej jednostki żywej itd., aż do całości światowej. Ona to jest obejmującą wszystko istotą żywą. Takimi są, np.: w filozofii starożytnej systemy Arystotelesa i Platona; w nowożytnej systemy Giordano Bruno, Leibniza; w najnowszej - doktryny Fechnera ${ }^{32}$, Wundta ${ }^{33}$, Ed.

\footnotetext{
${ }^{28}$ W oryginale: „такіе ступени жизни”. Łosski dokonuje tu paraleli między ewolucją a ogólnie rozumianym życiem, które jest potencjalnie skierowane na ustawiczny rozwój.

${ }^{29}$ W oryginale: „сверхбіологическіе”.

${ }^{30} \mathrm{~W}$ oryginale pada tu słowo odnoszące się do społeczności - „общество”. W języku polskim mówi się o takiej wspólnocie jako o rodzinie pszczelej. Zob., np. Trzybiński S., Wielki Poradnik Pasieczny, https:// pasieka24.pl/index.php/pl-pl/biblioteczka-pszczelarza-z-pasja-.siazki-pasieki/148-k129-wielki-poradnikpasieczny/1534-2-rodzina-pszczela (dostęp: 28.10.2019).

${ }^{31}$ Zob. mój artykuł: 'Organiczna struktura społeczeństwa i demokracji' («Органическое строеніе общества и демократія»), „Notatki ze współczesności” («Современные Записки»), nr 25 i 27.

"Современные Записки" był to magazyn literacki rosyjskiej emigracji w Paryżu, publikowany nieregularnie w latach 1920-1940. Artykuł o którym wspomina autor nie został przełożony na język polski.

32 Gustav Theodor Fechner (1801-1887),niemiecki fizyk i filozof. Był twórcą psychofizyki i inicjatorem eksperymentalnych badań nad zjawiskami psychicznymi. Największym dokonaniem Fechnera było ustalenie, wspólnie z bratem - Ernstem Heinrichem Weberem, prawa głoszącego, że przyrost wrażenia (subiektywnie odczuwanej różnicy) jest zależny od siły (wielkości) bodźca w sposób logarytmiczny. Prawo to, znane jako prawo Webera-Fechnera, uważane jest za podstawę psychofizyki.

${ }^{33}$ Wilhelm Maximilian Wundt (1832-1920) - niemiecki psycholog, filozof. W 1879 roku założył w Lipsku słynne laboratorium psychologiczne. Data ta jest uważana za początek psychologii klasycznej
} 
Hartmanna ${ }^{34}$, W. Sterna „Osoba i rzecz”35, Łosskiego „Świat jako organiczna całość,36 i wiele innych.

Jeśli zgadzamy się z takimi doktrynami dotyczącymi struktury świata, to trzeba będzie przyznać, że przed każdym człowieczym ‘ja’ stoją dwa zadania. Po pierwsze: kształcić się ku temu, ażeby być doskonałym organem wyższej całości, mianowicie tych społecznych jedności (rodziny, państwa, narodu itp.) do których człowiek przynależy, nadto zaś, uniwersalnej całości Królestwa Bożego, do którego wiedzie nas Kościół. Po drugie: przygotowywać się ku temu, ażeby w hierarchii życia organicznych jednostek zająć pozycję wyższą, aniżeli ludzkie istnienie.

Treść pierwszego zadania realizuje każdy kulturalny człowiek, a zawiera się ona w tym, aby być przyzwoitym członkiem rodziny, dobrym patriotą, wiernym synem Kościoła itp. - dlatego też nie będę więcej o niej mówił. Drugie zadanie przedstawia sobą coś wielce osobliwego, zrozumiałego tylko temu, kto rozważał wymienione powyżej teorie filozoficzne, np. w doktrynie Fechnera. Dla jasności zilustruję wyraźnie w czym rzecz.

Zgodnie z takimi teoriami, na przykład, cała nasza planeta, Ziemia, jest istotą żywą, obdarzoną jedną świadomością. Wszelkie postrzeżenia pojedynczych istot żyjących na ziemi, ludzi, zwierząt, roślin, a także wszelkie ich uczucia i dążenia złączone są w jednej świadomości Ziemi w jedno całościowe postrzeganie oraz wiedzę. Również uczucia i partykularne wole na tej podstawie komplikują się w nieskończenie bogatsze, jak również znacznie pełniejsze w treść, niż wszystko, co można znaleźć w naszej indywidualnej świadomości.

Pojedyncze życie jest właściwe Ziemi na ogromną skalę, w mniej złożonej formie właściwej każdemu mniej lub bardziej odrębnemu jej fragmentowi, np. Parkowi Narodowemu Yellowstone w Stanach Zjednoczonych Ameryki lub Harz w Niemczech. Rozwijając w sobie siły organiczne człowiek może poszerzyć swoje bycie. Może on osiągnąć stan, w którym jego ciało będzie takim całym fragmentem Ziemi a organami jego działalności będą nie dwie ręce, dwie nogi, lecz całe żywe istoty, a także potoki, pokłady ziemi, itp., które wchodzą w skład tego fragmentu Ziemi. Ażeby wznieść się na taki, wyższy poziom bycia, należy rozwijać w sobie zdolność bezpośredniego widzenia, żywego odczuwania obcego życia, z takąż

\footnotetext{
${ }^{34}$ Eduard von Hartmann(1842-1906), filozof niemiecki. Głosił teorię pesymizmu historiozoficznego, pragnąc pogodzić filozofię Schopenhauera z koncepcjami Schellinga oraz Hegla. Sławę przyniosła mu książka Filozofia nieświadomego.

${ }^{35}$ W oryginale: „"Person und Sache»”. Nietłumaczona na polski książka Williama Sterna (1871-1938). Był to niemiecki psycholog i filozof. Uznawany za jednego z twórców personalizmu psychologicznego i psychologii różnic indywidualnych; pionier badań nad inteligencją. Wprowadził pojęcie ilorazu inteligencji.

${ }^{36}$ W oryginale: „"Міръ какъ органическое цьлое»”.
} 
konkretną pełnią i z takimże żywym uczestnictwem, jakie osiągamy w stosunku do swojego ciała. Na podstawie tak żywego odczuwania można rozwinąć w sobie następnie umiejętność takiego zrastania się z czyimś życiem, ażeby działać w innym stworzeniu, łącząc z nim swoje siły tak, jak działamy w swoich organach, mięśniach rąk, nóg, itp.. Carpenter ${ }^{37}$, współczesny filozof angielski, utrzymując poglądy zbliżone do doktryny Fechnera, w swojej książce Miłość $i$ śmierć $^{38}$ (gdzie stawia pytanie, o to jak rozwinąć w sobie umiejętność kochania i godnego umierania) utrzymuje, że człowiek przygotowawszy się do takiego rozszerzenia świadomości i skomplikowania ciała, może przejść w nową formę bycia bez gwałtownego rozdarcia, nawet bez chwilowej ${ }^{39}$ utraty świadomości.

Porównamy teraz dwa sposoby życia - techniczny i organiczny. Technika nie tworzy wewnętrzne, lecz zewnętrzne zjednoczenie człowieka ze światem. Wytwarza ona komunikację ze światem, ale ta komunikacja nie wznosi człowieka na ontologicznie wyższy poziom: siły przyswojenia pozostają w dawnej postaci, a ilość przyswojonego materiału nadzwyczajnie wzrasta. Stąd występują naruszenia harmonii życia psychicznego oraz cielesnego, szczególnie w postaci nerwic. Najgorszym jest to, że nadmierny zachwyt techniką może doprowadzić człowieka na drogę, na której wyższe zdolności nie tylko przestają się rozwijać, ale i są wygaszane - pod wpływem substytutu, dajmy na to radia, samochodów, itp., zainteresowanie nimi i potrzeba ich rozwijania może zniknąć.

Oczywiście, wskazując na ten mankament kultury technicznej, ja w ogóle nie zalecam rezygnacji $z$ nowoczesnej techniki. $Z$ racji tego, że stoimy na niższym stopniu rozwoju duchowego, potrzebne nam jest nie tylko tworzenie wyższych organów, lecz także dodatkowe wsparcie w formie posługiwania się narzędziami. Jest to zadanie, o którym mówią okultyści, jogini, magowie itp.. Jednakże ja formułuję to pytanie nie w ramach ich nauk, dlatego że oferowane przez nich ścieżki rozwoju, medytacja, wykształcenie potężnej woli, magiczne oddziaływanie na świat, itp., są wątpliwe. Siła uzyskana tymi sztucznymi,

37 Edward Carpenter (1844-1929) był angielskim pisarzem i myślicielem społeczny utożsamiany $z$ antyindustrialnym ruchem artystycznym Arts and Crafts Movement, zrzeszającego rzeźbiarzy, malarzy, ale też architektów i rzemieślników w myśl tworzenia sztuki użytkowej, która miała służyć całemu społeczeństwu. Bardziej interesowała go reforma społeczeństwa i powrót do wiejskiego rzemiosła niż rewolucja polityczna. W jego pracach znaleźć można inspiracje, m.in. twórczością Henry'ego Thoreau.

${ }^{38}$ W oryginale: " "Любовь и смерть»". Książka, którą wzmiankuje tu Łosski, ukazała się w Londynie, w roku 1912. Jej angielski tytuł jest nieco dłuższy i brzmi: The Drama of Love and Death: A Study of Human Evolution and Transfiguration, co po polsku można oddać jako Dramat miłości i śmierci: studium ludzkiej ewolucji i przemienienia. Ten nietłumaczony na język polski tekst odnaleźć można bez trudu w internecie.

${ }^{39}$ W oryginale: „мимолетной”. 
mimozowatymi ${ }^{40}$ środkami, niezabezpieczonymi przed diabelskimi pokusami, z łatwością może wejść na drogę zaborczości ${ }^{41}$, egocentrycznego podporządkowania sobie świata.

Istnieje i inny sposób, wynikający prosto $\mathrm{z}$ chrześcijańskiego ideału, mający w perspektywie nie doczesne dobra ziemskie, lecz cel ostateczny: królestwo wolnej i miłującej jedności wszystkich istot, w których „Bóg jest wszystkim we wszystkim”, w którym wszystkie istoty w sposób wolny łączą się w „Jedno Ciało i Jeden Duch”.

Uniwersalny $^{42}$ organizm, o którym mówi religia chrześcijańska, istnieje już nawet i tutaj, na nieprzeobrażonej jeszcze ziemi ${ }^{43}$, chociaż po prawdzie, jeszcze w powijakach. Nie musimy go tworzyć od początku, musimy jedynie, z Bożą pomocą, wspomagać jego rozwój. Zadanie to jest analogiczne do tego, o którym mówiłem rozmyślając o udoskonalaniu naszego ludzkiego ciała drogą oczyszczenia duszy, które to harmonizuje nasze życie psychiczne i fizyczne. Istotnie, także i ujawnienie nowych umiejętności i stworzenie nowych organów, wznoszenie nas na wyższy poziom w uniwersalnym organizmie oraz zbliżenie go (tegoż organizmu) i nas do ideału - niezawodnie osiąga się to wszystko tymi samymi środkami: oczyszczeniem uczuć i woli, harmonijnym odniesieniem do świata, wzrastaniem w nas miłości skierowanej do wszystkich stworzeń i ku Bogu.

\footnotetext{
${ }^{40}$ Tj. delikatnymi, nazbyt wrażliwymi, zbyt mało odpornymi na przeciwności. W oryginale: „тепличными”.

${ }^{41}$ W oryginale: „хищничества”.

${ }^{42}$ W oryginale: „Вселенский”.

${ }^{43}$ Zob. Ap 21, 1.5.
} 